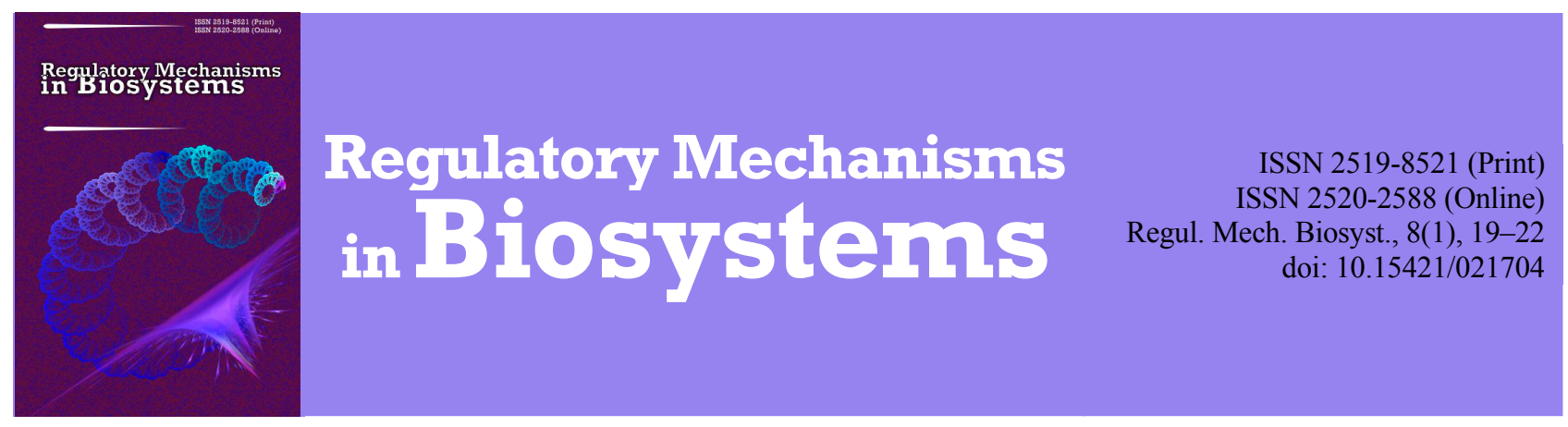

\title{
Changes in the arteries in the course of hypertensive disease and extrasystoles
}

\author{
N. V. Didyc, O. V. Lysunets \\ Vinnytsa National Medical University named by N. I. Pirogov, Vinnytsa, Ukraine
}

Article info

Received 04.12.2016

Received in revised form 15.01.2017

Accepted 20.01.2017

Vinnytsa National

Medical University

named by N.I. Pirogov,

Pirogov Str., 56,

Vinnytsa, 21018, Ukraine

Tel.: +38-063-629-66-45

E-mail:lysunets@mail.ru

\author{
Didyc, N. V., \& Lysunets, $O$. V. (2017). Changes in the arteries in the course of hypertensive disease and \\ extrasystoles. Regulatory Mechanisms in Biosystems, 8(1), 19-22. doi: 10.15421/021704
}

Our research is focused on study of changes in the intima-media vascular wall of patients suffering from hypertensive disease as well as patients suffering from hypertensive disease and coexistent extrasystole. We examined 120 patients ( 42 men and 78 women) between the ages 27 to 81 suffering from hypertensive disease of the II stage as defined by the Ukrainian Association of Cardiologists and extrasystoles (more than 30 episodes per hour of research) of different topography and 30 persons (13 men and 17 women) suffering from hypertensive disease of the II stage between the ages 30 to 76 without rhythm disturbance. The first clinical group was formed of $54(45 \%)$ patients suffering from repeated supraventricular extrasystoles. The second clinical group was formed of $42(35 \%)$ patients suffering from repeated ventricular arrhythmia. The third group was formed of $24(20 \%)$ patients suffering from both repeated supraventricular extrasystoles and ventricular extrasystoles. The results of treatment demonstrate that the existence of repeated supraventricular extrasystoles and ventricular extrasystoles in patients suffering from hypertensive disease of the II stage in contrast to patients without arrhythmia and repeated supraventricular extrasystoles is associatesd with severer vascular dysfunction, which is defined by signs of rather high rigidity of the large arteries (significant reduction of original size of brachial artery diameter), severer defects of endothelium-dependant vasodilation (reduction of increment value of brachial artery diameter during the test with decompression, reduction of periodicity of registration of normal reaction and increase of paradoxical vasoconstriction of the brachial artery during the test with decompression) and significant reduction of general vasodilational potential, increase of frequency of cases with dissociation in the nature of endothelium-dependant and endothelium-independent reaction of the brachial artery. The latter changes were registered in $90(60.0 \%)$ of examined patients, the most frequent of their variants were: 1) reduced reaction of the brachial artery for decompression + normal response in the test with nitroglycerine $(29.7 \%)$ and 2) paradoxical vasoconstriction in response to decompression + reduced reaction on taking nitroglycerine (22.4\%).

Keywords: arrhythmia; changes of intima-media vascular wall; hypertensive disease

\section{Зміни артерій за гіпертонічної хвороби та екстрасистолії}

\author{
Н. В. Дідик, О. В. Лисунець \\ Вінницький національний медичний університет імені М. І. Пирогова, Вінниця, Украӥна
}

Обстежено 120 пацієнтів із гіпертонічною хворобою II стадії та частою екстрасистолією (чинний наказ МОЗ від 03.07.2006 p. № 436) віком від 27 до 81 року. Групу контролю склало 30 хворих із гіпертонічною хворобою II стадії без будь-яких порушень серцевого ритму віком від 40 до 74 років. Згідно з топічним варіантом екстрасистолії, першу клінічну групу склали $54(45,0 \%)$ пацієнти 3 частою суправентрикулярною екстрасистолією, другу - 40 (33,3\%) хворих із частою шлуночковою екстрасистолією і третю - 26 (21,7\%) хворих із суправентрикулярною та шлуночковою екстрасистолією. Всім хворим проводили загальноклінічне обстеження, електрокардіографічне дослідження у 12 загальноприйнятих відведеннях, добове моніторування артеріального тиску, холтерівське моніторування електрокардіографії, ехокардіографічне дослідження, соноехографію, оцінювання судинорухової функції плечової артерії. Шлуночкова та комбінована екстрасистолія у хворих із гіпертонічною хворобою II стадії, на відміну від хворих без аритмій із частої суправентрикулярної екстрасистолії, асоціюється з більш тяжкою судинною дисфункцією, тяжкими порушеннями ендотелійзалежної вазодилатації та зменшенням загального вазодилатувального потенціалу, зростанням частоти випадків із дисоціацією в характері ендотелійзалежної та ендотелійнезалежної реакції плечової артерії.

Ключові слова: серцево-судинна система; гіпертензія; аритмії; екстрасистолія

Вступ

Питання вивчення ланок патогенезу артеріальної гіпертензії та порушень серцевого ритму залишаються актуальними протягом останнього десятиріччя. Адже, відповідно до даних
Всесвітньої організації охорони здоров'я, артеріальна гіпертензія щорічно призводить до смерті понад 17 млн осіб. I, прогностично, до 2030 року цей показник сягне 24 млн осіб. Станом на 2016 рік в Україні 12 млн осіб мають артеріальну гіпертензію, що складає $46,8 \%$ серед хвороб серцево-судинної системи 
дорослого населення. А $81 \%$ хворих на артеріальну гіпертензію мають неконтрольований перебіг гіпертонії (Lutaj, 2016). В Україні стандартизований показник поширеності артеріальної гіпертензії у міській популяції становить 29,6\% як у чоловіків, так і у жінок. У сільській популяції поширеність артеріальної гіпертензї вища - 36,3\% (серед чоловіків - 37,9\%, серед жінок - 35,1\%). Під час аналізу структури артеріальної гіпертензії за рівнем артеріального тиску у половини хворих виявлено артеріальну гіпертензію першого ступеня, у кожного третього хворого - артеріальну гіпертензію II ступеня, у кожного п’ятого - артеріальну гіпертензію III ступеня. Серед осіб із підвищеним артеріальним тиском знають про наявність артеріальної гіпертензії 67,8\% сільських та 80,8\% міських жителів. Систематично лікуються 38,3\% жителів сіл і 48,8\% міських мешканців. Ефективність лікування складає, відповідно, $8,1 \%$ та $18,7 \%$ (Klinichna nastanova arterialna hipertenziia onovlena ta adaptovana zasnovana na dokazach, 2012 [Clinical setting the arterial hypertension is renewed and the adapted is based on proofs]). Наявність артеріальної гіпертензії підвищує ризик загальної смертності в 4,5 раза в чоловіків та удвічі у жінок. Наявність артеріальної гіпертензії не лише збільшує ризик загальної смерті, а і скорочує середню тривалість життя у чоловіків на 9 років та у жінок на 7 років (Nakaz MOZ Ukrainy. Pro zatverdzhennja ta vprovadzhennja medyko-tekhnologichnykh dokumentiv zi standartyzaciji medychnoji dopomogy pry arterialnij gipertenziji. 24.05.2012. № 384).

Патогенез артеріальної гіпертонії залучає механізми взаємовідносин нейроендокринної, гуморальної регуляції, об'ємів серцевого викиду та циркулюючої крові, периферичного опору судин (Hajkosseing et al., 2015; Pancholy et al., 2015; Budoff, 2016). Порушення серцевого ритму як предиктор ускладнень артеріальної гіпертонії та ішемії міокарда актуальні для вивчення на сучасному етапі розвитку кардіології (Coronel et al., 2012; Raragueuzian, 2013; Gula et al., 2014). Консервативна терапія артеріальної гіпертензії, поєднаної 3 порушеннями серцевого ритму, проводиться поряд з оперативним лікуванням (Crotti, 2011; Piccini et al., 2012). Науковці виокремлюють роль інтими-медіа судин в патогенезі серцево-судинних захворювань (Rasputina, 2012). Зміни інтими-медіа каротидних артерій розглядаються як маркер кардіоваскулярного ризику серцевосудинних ускладнень (Michiel et al., 2014). Доведено асоціацію між товщиною інтіми-медіа сонних артерій і підвищенням артеріального тиску у людей похилого віку та дітей, відповідно (Staboulis, 2012; Oishi et al., 2013). Із цієї позиції, наше дослідження поглиблює вивчення морфофункціональних змін серцевосудинної системи за гіпертонічної хвороби та екстрасистолії (Didyk, 2009; Didyk, 2010) та має зв'язок із вивченням даної проблеми у світі (Chen et al., 2015). Мета нашого дослідження виявити відмінності змін інтими-медіа судинної стінки у хворих як із гіпертонічною хворобою, так і з гіпертонічною хворобою, поєднаною з екстрасистолією.

\section{Матеріал і методи досліджень}

У дослідження включили 120 пацієнтів із гіпертонічною хворобою II стадії та частою екстрасистолією віком від 27 до 81 року. Серед них - $42(35,0 \%)$ чоловіки і 78 (65,0\%) жінки, співвідношення чоловіків до жінок $-1: 1,9$. Контрольну групу склали 30 осіб із гіпертонічною хворобою II стадії без будьяких порушень серцевого ритму віком 40-74 років. Серед них 13 (43,3\%) чоловіків і 17 (56,7\%) жінок, співвідношення чоловіків до жінок - $1: 1,3$. Усі пацієнти проходили стаціонарне лікування у відділенні денного стаціонару кардіологічного профілю міської клінічної лікарні № 1 Вінниці. Показаннями до включення хворих у дослідження були гіпертонічна хвороба II стадії за рекомендаціями Української асоціації кардіологів (2008) та чинного наказу МO3 України від 03.07.2006 № 436, верифікована за даними холтерівського моніторування електрокардіографії часта екстрасистолія з симптомним пере- бігом, яка, згідно із сучасними рекомендаціями Європейського товариства кардіологів, потребує постійної антиаритмічної терапії, відсутність протипоказань до прийому бетаадреноблокаторів і соталолу та інформаційна згода хворого взяти участь у дослідженні.

Протипоказаннями до включення в дослідження були гіпертонічна хвороба I або III стадій, серцева недостатність IIa-IIб стадій за М. Д. Стражеска - В. Х. Василенко і III-IV функціональний клас за NУHA та наявність ЕхоКГ-ознак систолічної дисфункції міокарда ЛШ (ФВ < 45\%), безсимптомна екстрасистолія та екстрасистолія, яка, згідно із сучасними рекомендаціями Свропейського товариства кардіологів, не потребує постійної антиаритмічної терапії, наявність пароксизмальної та постійної форми фібриляції передсердь, пароксизмальних тахікардій та синдрому предекзитацій шлуночків, тяжкі захворювання дихальної системи та шлунково-кишкового тракту, захворювання щитоподібної залози, цукровий діабет і злоякісні утворення, зловживання алкоголем і нейропсихічні розлади, небажання хворого брати участь у дослідженні.

Усім хворим основного клінічного масиву $(n=120)$ як стартовий антиаритмічний препарат призначено бетаадреноблокатор бісопролол у дозі 10 мг на добу. У разі недостатнього антигіпертензивного ефекту бісопрололу, який оцінювали на цільовій дозі протягом 10-12 діб, додатково призначали інгібітор ангіотензин перетворювального ферменту еналаприл у дозі 20-40 мг на добу. За недостатньої антигіпертензивної та антиаритмічної ефективності терапії з двох препаратів додатково призначали $\mathrm{S}(-)$ амлодипін у дозі 2,5-5,0 мг на добу. Антиаритмічний ефект вважали позитивним у разі повного зникнення або зменшення добової кількості екстрасистол через 1 місяць більше ніж на 50\%. У разі негативного антиаритмічного ефекту бісопрололу призначали соталол у дозі 160 320 мг на добу. За позитивного антиаритмічного ефекту призначене лікування продовжували протягом 6 місяців.

Усім хворим проводили комплексне клініко-інструментальне обстеження, яке включало загальноклінічне обстеження хворого, електрокардіографічне дослідження у 12 загальноприйнятих відведеннях, добове моніторування артеріального тиску, холтерівське моніторування електрокардіографії, ехокардіографічне дослідження у М-, В- і Д-режимах, соноехографію, оцінку судинорухової функції плечової артерії. Ендотеліальну дисфункцію судинного тонусу вивчали, проводячи пробу 3 компресією плечової артерії за D. Celemajer, де післяоклюзійне зростання діаметра судини має збільшуватись на 10\% порівняно з вихідним. Статистичну обробку результатів дослідження проводили за допомогою методів варіаційної статистики з використанням програм Statistica 6.0 (StatSoft Inc., USA).

\section{Результати}

Середня товщина інтими-медіа як у групах дослідження, так і в контрольній групі коливалась від 0,90 до $1,10 \mathrm{~cm}$ i суттєво не перевищувала визначений для популяції норматив ( $<0,9$ см). Аналізуючи показники судинорухової функції плечової артерії, виявляється, що у пацієнтів із гіпертонічною хворобою та частою суправентрикулярною екстрасистолією порівняно із хворими 3 гіпертонічною хворобою без аритмій реєстрували зменшення величини діаметра плечової артерії (показник $\mathrm{d}$ ПА, $\mathrm{P}=0,040$ ).

У хворих із гіпертонічною хворобою та частою шлуночковою екстрасистолією та хворих із гіпертонічною хворобою та комбінованою екстрасистолією, порівняно з хворими на гіпертонічну хворобу без аритмій, ці зміни були більш вираженими. В цих групах реєстрували достовірне зменшення діаметра плечової артерії (показник dПА, Р < 0,002), приросту діаметра плечової артерії на пробі з декомпресією $(\mathrm{P}<0,024)$ та амплітуди дилатації плечової артерії на пробах із декомпресією та нітрогліцерином (P < 0,040). Подібні зміни зареєстровані під 
час порівняння показників у групі пацієнтів із гіпертонічною хворобою та комбінованою екстрасистолією та хворих із суправентрикулярною екстрасистолією - визначали суттєве зменшення діаметра плечової артерії (показник dПА, P = 0,037), приросту діаметра плечової артерії на пробі з декомпресією $(\mathrm{P}=0,009)$ та амплітуди дилатації плечової артерії на провокаційних пробах $(\mathrm{P}=0,046)$. У пацієнтів із гіпертонічною хворобою та шлуночковою екстрасистолією порівняно $з$ пацієнтами із суправентрикулярною екстрасистолією, спостерігали суттєве зменшення приросту діаметра плечової артерії на пробі 3 декомпресією $(\mathrm{P}=0,046)$. У групі хворих із гіпертонічною хворобою та комбінованою екстрасистолією порівняно 3 усіма іншими групами, реєстрували суттєве збільшення індексу резистентності (показник RI, P < 0,05) та індексу пульсації (показник PI, P < 0,034). Це свідчить про суттєве зростання ригідності та погіршення еластичних властивостей великих судин у пацієнтів із гіпертонічною хворобою та комбінованою екстрасистолією.
Під час проведення провокаційних проб спостерігали, що у групах пацієнтів із гіпертонічною хворобою без аритмій і 3 частою суправентрикулярною екстрасистолією визначали однаковий розподіл різних реакцій плечової артерії на пробу 3 декомпресією. У 33,3\% і 25,9\% випадків реєстрували нормальну, у 53,3\% і 61,1\% випадків - знижену реакцію, у 13,4 і 13,0\% парадоксальну вазоконстрикцію. Характер реакції плечової артерії на пробі з декомпресією в різних групах хворих принципово відрізнявся від такого у групах хворих на гіпертонічну хворобу та гіпертонічну хворобу з частою шлуночковою екстрасистолією та комбінованою екстрасистолією. У цих пацієнтів визначали суттєве зменшення частоти реєстрації нормальної реакції (7,5\% і 3,8\% проти 33,3\% і 25,9\%, відповідно, $\mathrm{P}<0,041)$ та зростання парадоксальної вазоконстрикції $(35,0 \%$ і 34,7\% проти 13,4\% і 13,0\%, відповідно, Р < 0,041) за практично однакової частоти реєстрації зниженої вазодилатації (57,5\% і 61,5\% проти 53,5\% і 61,1\%, відповідно) (рис.).

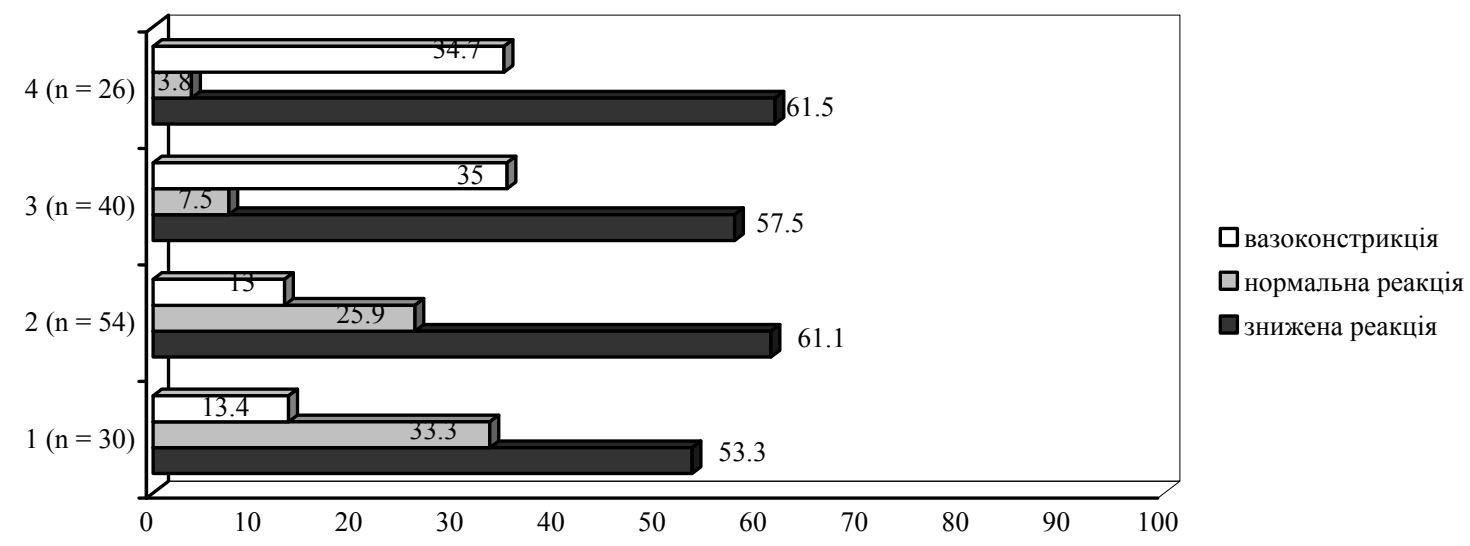

Рис. Характер реакції плечової артерії на проби з декомпресією в різних групах хворих

Аналізуючи отримані результати реакції плечової артерії на пробі з нітрогліцерином, бачимо практично однаковий розподіл різних типів реакцій $(\mathrm{P}>0,05)$ обстежених груп хворих. У більшості випадків $(60,0-73,1 \%$ хворих $)$ визначено зниження приросту діаметра плечової артерії на пробі з нітрогліцерином $<20 \%$ вихідної величини, в $33,3-19,2 \%$ реєстрували нормальну реакцію приросту діаметра плечової артерії на пробі з нітрогліцерином $>=20 \%$ вихідної величини та в $5,0-7,7 \%$ - парадоксальна вазоконстрикція у відповідь на прийом нітрогліцерину.

Результати нашого дослідження продемонстрували відсутність зв'язку між порушеннями ендотелійнезалежної вазодилатації плечової артерії та варіантом екстрасистолії хворих на гіпертонічну хворобу II стадії. Дисоціацію характеру ендотелійзалежної та ендотелійнезалежної реакції плечової артерії спостерігали практично в половини пацієнтів із гіпертонічною хворобою без аритмій і хворих із частою суправентрикулярною екстрасистолією (40,0\% і 50,0\% відповідно). У пацієнтів із частою шлуночковою та комбінованою екстрасистолією подібні зміни визначені у більшості випадків (72,5\% і 84,6\% відповідно), що суттєво перевищило частоту реєстрації у попередніх групах $(\mathrm{P}<0,029)$. Часта шлуночкова та комбінована екстрасистолія у хворих на гіпертонічну хворобу асоціюється із суттєвим зростанням частоти випадків із дисоціацією в характері ендотелійзалежної та ендотелійнезалежної реакції плечової артерії.

\section{Обговорення}

Протягом останніх років медична спільнота неодноразово порушувала питання ролі ендотелію в розвитку серцево-судинної патології, оскільки ендотелій в організмі людини підтримує гомеостаз через регуляцію тонусу судин (процеси вазоконстрикції та вазодилатації), будови стінки судин (процеси інгібіції та синтезу факторів фібринолізу та агрегації тромбоцитів), місцевого запалення (вироблення про- та протизапальних факторів). Дисфункція ендотелію - це дисбаланс між продукцією вазодилатаційних, ангіопротекторних, антипроліферативних факторів (простацикліну, тканинного активатора плазміногену, С-типу натрійуретичного пептиду, ендотеліального гіперполяризувального фактора) та вазоконстриктивних, тромботичних, проліферативних факторів (ендотеліну, супероксид-аніона, тромбоксану-2, інгібітора тканинного активатора плазміногену). Результати аналізу структурного ремоделювання сонних артерій і судинорухової функції плечової артерії відображали характер змін діаметра правої плечової артерії на пробі з реактивною гіперемією та нітрогліцерином свідчили про відсутність принципових відмінностей показником товщини інтима-медіа сонних артерій в обстежених групах хворих.

Виміряна товщина інтими-медіа у пацієнтів від 0,90 до 1,10 см не перевищувала визначений для популяції норматив ( $<0,9$ см). Це пояснюється включенням у дослідження хворих із неускладненим перебігом гіпертонічної хвороби. Хоча відомий нині факт - наявність тісного кореляційного зв'язку між товщиною інтими-медіа та частотою різних серцево-судинних ускладнень (Dhananjay et al., 2014). Цим пояснюється зростання товщини інтими-медіа в пацієнтів з ускладненим перебігом гіпертонічної хвороби - пацієнтів із III стадією хвороби, яких за запланованим дизайном дослідження ми не включили в розробку.

Результати нашого аналізу свідчать про відсутність суттєвих змін характеру ремоделювання сонних артерій i принципові порушення судинорухової функції плечової артерії у хворих на гіпертонічну хворобу без порушень серцевого ритму (контрольна група) i частою суправентрикулярною екстрасистолією (І клінічна група) та пацієнтів із частою шлуночковою екстрасистолією (II клінічна група) та комбінованою екстрасистолією (III клінічна група), що характеризувалось ознаками підвищеної 
ригідності плечової артерії (суттєве зменшення діаметра плечової артерії за відсутності змін ії відносної товщини), тяжчими порушеннями ендотелійзалежної вазодилатації (зменшення приросту діаметра плечової артерії на пробі 3 декомпресією) та загального вазодилатувального потенціалу (зменшення амплітуди дилатації плечової артерії на провокаційних пробах).

Отримані дані свідчать, що часта шлуночкова екстрасистолія та комбінована екстрасистолія за гіпертонічної хвороби II стадії асоціюється 3 тяжчими порушеннями судинорухової функції артерій (Didyc, 2016). Наявність частої шлуночкової та комбінованої екстрасистолії у хворих на гіпертонічну хворобу II стадії асоціюється з тяжчими порушеннями ендотелійзалежної вазодилатації, що характеризується зменшенням частоти реєстрації нормальної реакції та збільшенням парадоксальної вазоконстрикції плечової артерії на пробі 3 декомпресією. Наші результати співставляються з літературними даними щодо ролі інтими-медіа ендотеліальної дисоціації в патогенезі серцевосудинних захворювань (Michiel et al., 2014). Залишається відкритим питання відмінності в ендотеліальній дисфункції у пацієнтів із гіпертонічною хворобою II стадії, гіпертонічною хворобою II стадії та суправентрикулярною екстрасистолією та наявністю прогностично несприятливої поєднаної надшлуночкової та шлуночкової екстрасистолії у пацієнтів із гіпертонічною хворобою II стадії.

\section{Висновки}

У хворих із гіпертонічною хворобою II стадії часта шлуночкова та поєднана (надшлуночкова та шлуночкова) екстрасистолія корелює з важчою судинною дисфункцією, що полягає, по-перше, у зростанні ригідності артерій (зменшенні показника вихідного діаметра плечової артерії), по-друге - важчому прояві порушень ендотелійзалежної вазодилатації. Воно характеризується зменшенням показника величини приросту діаметра плечової артерії на пробі з декомпресією, зменшенням частоти реєстрації нормальної реакції та збільшенням частоти парадоксальної вазоконстрикції плечової артерії на пробу 3 декомпресією, зменшенням загального вазодилатувального потенціалу, зростанням частоти випадків із дисоціацією характеру ендотелійзалежної та ендотелійнезалежної реакції плечової артерії. Вищезгадані зміни реєстрували в $60,0 \%$ обстежених пацієнтів, при цьому найчастішими їх варіантами були, по-перше, знижена реакція плечової артерії на декомпресію та нормальна відповідь на пробу з нітрогліцерином, яку реєстрували у $29,7 \%$ випадків та, по-друге, парадоксальна вазоконстрикція у відповідь на декомпресію та знижена реакція на прийом нітрогліцерину, яку реєстрували у $22,4 \%$ випадків.

Результати нашого дослідження продемонстрували відсутність предикторів для виключення спільних патогенетичних механізмів розвитку судинної дисфункції та патогенетичного аритмогенезу у хворих із гіпертонічною хворобою. Цей факт потребує подальшого дослідження як із погляду патогенезу гіпертонічної хвороби, так і з погляду патогенезу екстрасистолій у розвитку аритмології.

\section{References}

Bots, M. L., Groenewegen, K. A., Anolersa, T. J., Britton, A. R., Dekker, J. M., Engstrom, C., Evans, G. W., de Graaf, J., Grobbee, D. E., Hedblad, B., Hofman, A., Holewijn, S., Ikeda, A., Kavousi, M., Kitagawa, K., Kitamura, A., Ikram, M. A., Lonn, E. M., Lorenz, M. W., Mathiesen, E. B., Nijpels, G., Okazaki, S., Oleary, D. H., Polak, J. F., Price, S. F., Robertson, C., Rembold, C. M., Rosvall, M., Rundek, T., Salonen, J. T., Sitzer, M., Stehouwer, C. D. A., Francio, O. H., Peters S. A. E., \& den Ruijter, H. M. (2014). Common carotid intima-media thickness measurements do not improve cardiovascular risk prediction in individuals with elevated blood pressure. Hypertension, 63, 1173-1181.
Budoff, M. (2016). Triglycerides and triglyceride-rich lipoproteins in the causal pathway of cardiovascular disease. The American Journal of Cardiology, 118(1), 138-145.

Chen, Y., Huang, W., Xiong, H., Zhang, R., Lu, M., Wu, D., Pirbhulal, S., \& Wu, W. (2015). Relationship of short-term blood pressure variability with carotid intima-media thickness in hypertensive patients. Biomedical Engineering Online, 14(1), 71.

Coponel, R., Janse, M.J., Opthof, T., Wilde, A.A., \& Taggart, P. (2012). Postrepolarization refractoriness in accute ishemica and after antiarrhythmic drug administration: Action potential duration is not always an index of the refractory period. Heart Rhythm, 9(6), 977-982.

Crotti, L. (2011). Pleiotropic mutations in ion channels: What lies behind them. Heart Rhythm, 8(1), 56-57.

Didyk, N. V. (2009). Osobluvosti porushennia lipidtransportnoji fynkciji krovi i variabelnosti sertsevogo rytmu $\mathrm{u}$ hvorukh na gipertonichnu khvorobu, uskladneni riznymy variantamy ekstrasystoliji [The peculiarities of disorder of the lipid transport function of blood and the variations of cardiac rhythm for the patients with hypertension disease, which is complicated by different kind of extrasistole]. Visnuk Vinnyckoho Nacionalnoho Medychnoho Universytetu imeni M. I. Pirogova, 13(2), 527-530 (in Ukranian).

Didyk, N. V. (2015). Osoblyvosti strukturnoho remodeliuvannia arteriji pry hipertonichnij khvoroby II stadiji ta ekstrasystoliji [Peculiarities of structural remodeling of arteria in the course of hypertensive disease of the II stage and extrasystole]. Report of Morphology, 21, 158-161 (in Ukranian).

Didyk, N. V. (2016). Dyslipidemija u patsientiv iz arterialnoju hipertenzijeju i ekstrasystolijeju [Dyslipidemia in patients with arterial hypertension and extrasystoles]. Visnyk of Dnipropetrovsk University. Biology, Medicine, 7(2), 73-77 (in Ukranian).

Didyk, N. V., \& Ivanov, V. P. (2010). Osobluvosti cyrkadnoji regulaciji arterialnogo tysku i rytmu sercia, chastota reestracii epizodiv ichemiji miokardu u hvorukh na gipertonichnu khvorobu $\mathrm{z}$ riznymy variantamy ekstrasystoliji [Features of circadian regulation and heart rhythm, registration frequency of episodes of myocardial ischemia in patients with essential hypertension and different forms of extrasystoles]. Arterialna Gipertenzia, 11, 29-37 (in Ukranian).

Gula, L. J., Leong-Sit, P., \& Skanes, A. C. (2014). Primary prevention pvi for atrial fibrillation weighing the ricks and benefits. Heart Rhythm, 11(9), 1573-1574.

Karagueuzian, H. S. (2013). The nervous kidney and ventricular fibrillation: A possible gemu changer? Heart Rhythm, 10(10), 1531-1532.

Lutaj, M. I. (2016). Efektyvnist kombinovanoji terapiji arterialnoji gipertenziji v Ukrajini: Rezultaty bagatocentrovogo doslidzehennja TRIUMF [Efficiency of the combined treatment of arterial hypertension in Ukraine: Results of the TRIUMF multicenter study group]. Ukrajinskyj Kardiologichnyj Zhurnal, 4, 17-28 (in Ukrainian).

Oishi, E., Kgiyama, S., Ohmori, S., Seki, T., Maebuchi, D., Kohno, O., Tominaga, M., \& Iida, M. (2013). Association of systolic blood pressure with carotid intima thickness in elderly Japanese patients. Clinical and Experimental Hypertension, 35(4), 273-278.

Pancholy, S. B., Shantha, G. P. S., Patel, T. M., Sobotka, P. A., \& Kandzari, D. E. (2015). Meta-analysis of the effect of renal denervature on blood pressure and pulse pressure in patients with resistant systematic hypertension. The American Journal of Cadiology, 114(6), 856-861.

Piccini, J. P., Mi, X., Hernandez, A. F., Curttis, L. H., Dewald, T. A., Go, A. S. (2012). Pharmacotherapy in medicare beneficiaries with atrial fibrillation. Heart Rhythm, 9(9), 1403-1408.

Rasputina, L. V. (2012). Osoblyvosti endotelijzalezhnoji vazodylatatsiji ta strukturno-funktsionalnoho remodeliuvannia sertsia u khvorykh z poiednanym perebihom khronichnoho obstruktyvnoho zakhvoriuvannia lehen ta hipertonichnoji khvoroboy [Peculiarities of endothelial-dependent vasodilation and structural and functional remodeling of the heart in patients with chronic obstructive pulmonari disease and concominant systemic hypertension]. Ukrainian Pulmonology Journal, 2, 55-58 (in Ukrainian).

Stabouli, S., Kotsis, V., Karagianni, C., Zakapoulos, N., Konstantopoulos, A. (2012). Blood pressure and carotid artery in intima-media thickness in children and adoles rentis: the role of obesity. Hellenic Journal of Cardiology, 53(1), 41-47.

Vaidya, D., Bennett, W. L., Sibley, C. T., Polak, J. F., Herrington, D. M., \& Ouyang, P. (2014). Association of parity with carotid diameter and distensibility multi-ethnic study of atherosclerosis. Hypertension, 64, 253-258.

Werdan, R., Ebelt, H., Nuding, S., Hopfner, F., Muller-Werdan, U., Stock1, G. (2015). Ivabradine in combination with beta-blockers in patients with chronic stable angina after percutaneous coronary intervention. Advances in Therapy, 32(2), 120-137. 